\title{
The Role of Institutional Quality on Participation in Global Value Chains*
}

\author{
El papel de la calidad institucional en la \\ participación en las cadenas globales de valor
}

\author{
Javier Barbero \\ Joint Research Centre (JRC), European Commission \\ Ernesto Rodríguez-Crespo \\ Universidad Autónoma de Madrid
}

\begin{abstract}
We explore the effect of institutional quality on participation in global value chains (GVCs) by distinguishing between backward and forward participation. Using a sample of 63 OECD and non-OECD countries during the period 2005-2015, the results obtained from a panel data estimation are twofold. First, we obtain a positive association between institutional quality and participation in GVCs, with slightly greater effects for backward than for forward participation. Second, we find that results are sensitive to the dimension of the institutions considered, with Voice and Accountability being associated with more backward participation, and Rule of Law and Political Stability with more forward participation.
\end{abstract}

Keywords: institutional quality, backward participation, forward participation, panel data, international trade.

JEL Classification: F14, E02.

\section{Resumen}

Se analiza el efecto de la calidad institucional en la participación en las cadenas globales de valor $(C G V)$ distinguiendo entre participación hacia atrás y hacia delante. Utilizando una muestra de 63 países miembros y no miembros de la OCDE a lo largo del periodo 2005-2015, los resultados obtenidos a partir de una estimación con datos de panel reflejan una doble evidencia. En primer lugar, se obtiene una relación positiva entre calidad institucional y participación en $C G V$, que registra efectos ligeramente mayores para la participación hacia atrás que para la participación hacia delante. En segundo lugar, se encuentra que los resultados son sensibles a la dimensión de las instituciones considerada, ya que Voz y Rendición de Cuentas está asociada positivamente con mayor participación hacia atrás, mientras que Estado de Derecho y Estabilidad Política se relacionan positivamente con la participación hacia delante.

Palabras clave: calidad institucional, participación hacia atrás, participación hacia delante, datos de panel, comercio internacional.

Clasificación JEL: F14, E02.

* The authors are grateful to Joanna Bashford for useful comments and suggestions. Authors acknowledge support from Madrid's Directorate General of Research and Technological Innovation (Grant H2019/JHUM5761). The views expressed are purely those of the authors and may not in any circumstances be regarded as stating an official position of the European Commission. 


\section{Introduction}

The production of goods is internationally fragmented, with different parts being produced in diverse countries around the globe. These components are assembled along the value chain, and value added is incorporated to each step of the international production process (Antràs \& Chor, 2013; Johnson, 2014; Baldwin, 2016; Alfaro et al., 2019; among others). Nevertheless, this network structure is not resilient to external economic shocks. The current COVID-19 crisis is expected to dampen and reshape trade relationships, and global value chains (henceforth, GVCs), might be seriously threatened, reshuffling the patterns and structure of global production networks. Although GVCs account for around half of total world trade (World Bank, 2020), a considerable number of questions needs to be addressed by empirical studies in order to shed some light on current trade patterns with a view to gaining robustness in the face of future economic shocks. One of the most important issues is the diffusion of information through the participants in GVCs, which remains largely unexplored in the academic literature (Bernard \& Moxnes, 2018). However, the existence of contractual and information frictions represents serious obstacles to the diffusion of knowledge along GVCs.

Among the elements that can reduce these contractual and information frictions, institutions are cited as one of the major elements (Araujo et al., 2016) which can help to ease the diffusion of knowledge through GVCs (Nunn \& Trefler, 2014). Institutions are expected to impact positively on economic growth and development (Glaeser et al., 2004; Acemoglu \& Robinson, 2012, among others). Although the study of institutions is difficult due to the lack of an operational and universal definition (Nunn \& Trefler, 2014) that may complicate the empirical study, measures based on citizens' feelings have been developed. The main problem related to these measures is the high degree of subjectivity (Rodríguez-Pose, 2013). Still, these indicators have become widely accepted as they capture different dimensions of institutions with an accurate degree. A less explored issue is the effect of institutions on economic performance in general and in particular on variables linked to international economics, such as trade and foreign direct investment.

Studies regarding the effects of institutions on trade present avenues for further research, especially concerning the field of GVCs. The impact of institutions on trade has attracted attention, especially since the works of Levchenko (2007) and Nunn (2007). Nevertheless, the main body of empirical studies covering the effect of institutions on trade has only considered the gross exports of goods (Méon \& Sekkat, 2008; Francois \& Manchin, 2013; Fiankor et al., 2019; Martínez-Zarzoso \& Márquez-Ramos, 2019; Lin et al., 2020), services (Beverelli et al., 2017), or both (Álvarez et al., 2018). These studies do not distinguish between final goods and services or intermediates. Only a few studies have addressed the effect of institutions on participation in GVCs at the country level. In these studies, institutions are measured through institutional quality (Dollar \& Kidder, 2017; Ge et al., 2020) or financial development (e.g., Efogo, 2020 for Africa). Firm-level studies are scarce, except for Herlina and Kudo (2020) for Indonesia. 
Acknowledging the contribution of all the foregoing studies, the present article aims to measure the impact of institutional quality on GVCs participation, by considering different forms of the latter. In particular, we follow OECD (2019) and consider forward and backward participation. While backward participation in GVCs refers to downstream positions in the global production chain by incorporation foreign intermediate products, forward participation in GVCs points to upstream positions where domestic products are exported and transformed elsewhere. In other words, backward participation implies that a country imports foreign value added -through intermediate inputs which are embodied in the final goods the country exports. In contrast, forward participation refers to domestic value added that is incorporated in exports of foreign countries. While both ways of participating in GVCs allow technological spillovers to flourish, some marked differences arise. Backward participation yields a country the possibility of importing intermediate goods with high-quality technology from foreign countries, whereas forward participation is related to the acquisition of information about technology from trading partners to sell intermediate products (Urata \& Baek, 2020). ${ }^{1}$ Consequently, we hypothesize that information and contractual frictions may differ for both types of participation in GVCs, originating an asymmetric effect attributable to institutional quality. We test whether the effect of institutional quality on participation in GVCs differs for different dimensions of the former.

Using a sample of 63 countries over the period 2005-2015, our results suggest that institutional quality may have a positive effect on GVCs participation. However, the relationship is weaker than expected and the positive association can only be found for a reduced number of institutional quality indicators. The size of the coefficients suggests a slightly greater effect of institutional quality on backward participation in comparison to forward participation in GVCs. Moreover, we find that the effect of institutional quality on participation in GVCs is sensitive to different institutional dimensions.

This article is organized as follows. Section 2 depicts the research and methodological background, while Section 3 is devoted to the empirical analysis. Section 4 describes the results. Finally, Section 5 concludes.

\section{Research and methodological background}

\subsection{How to measure Global Value Chains and the importance of institutions}

Global Value Chains have completely reshaped trade relationships and the world geopolitical context. Instead of concentrating the complete production process within a single country, a network of multiple countries intervenes in the production

\footnotetext{
${ }^{1}$ Backward spillovers are where technology transfer is more likely to happen, as the recipient firm's demand can be oriented to inputs with high technology, which forces the supplier to upgrade the production process (ESCAP, 2015).
} 
of goods, and each country contributes a fraction of value added along the different steps of the production process. Once a product has crossed borders several times, gross exports cease to accurately reflect the total amount of domestic value added embedded in exports (Johnson, 2014; Koopman et al., 2014), given that the final exporter may not necessarily be the country contributing the largest share of value added.

Although these trade networks comprise both developed and developing countries, the latter tend to benefit the most: products that cross borders frequently due to the relaxation of trade barriers also increase substantially the gains from trade, which aims to reduce the existing gap in trade between developed and developing countries. This resurgence of developing countries has been known as the Rise of Middle Kingdoms (Hanson, 2012) and represents one of the major changes occurring during the New Globalization (Baldwin, 2016). These networks have been articulated through the centrality of countries such as China (Baldwin \& Tomiura, 2020), resulting in an increased vulnerability to the propagation of trade and financial shocks originated in those countries, as recently illustrated by the COVID-19 crisis. Despite this major shortcoming, GVCs have undoubtedly represented a window of opportunity for developing countries to maximize their gains from trade and globalization.

Although the dominance of GVCs in trade relationships is widely acknowledged, the measurement of participation in GVCs becomes complex, and both direct and indirect methodologies to identify country trade profiles have been developed. Indirect approaches assess the set of exported products in order to estimate whether a country needs to engage in GVCs to produce them. Economic complexity has become one of the most widely used measures of trade differences between countries involved in international production networks because they allow estimating the amount of knowledge embedded in a product (Hausmann et al., 2014). This measure relies on the concepts of product ubiquity and diversity: while product ubiquity is the number of countries that make the specific product, diversity is the total number of products for which the country has demonstrated to have a comparative advantage (Hausmann \& Hidalgo, 2011). Based on their performance within these two variables, countries can be ranked according to their product complexity, where greater product complexity is associated with more sophistication and hence a higher likelihood of having to engage in global networks in order to participate in the production process. According to our results, we not only expect cross-country differences between high and low -and middle- income countries due to their asymmetric production structures, but also between countries with similar levels of economic development. Table 1 illustrates these differences by comparing the trade profiles of Spain and Japan in 2015.

Table 1 displays salient differences between the set of products exported from Spain and Japan. While manufactured goods absorb a high percentage of the total exports in both countries (55.69\% and $68.53 \%$ for Spain and Japan, respectively), the amount is higher for Japan due to the strong orientation of the economy to sectors such as electronics, transport and machinery. In contrast, compared to Japan, Spain 
TABLE 1

GROSS EXPORTS OF SPAIN AND JAPAN IN 2015

(\% of total exports)

\begin{tabular}{|l|r|r|}
\hline \multicolumn{1}{|c|}{ Sector } & Spain & Japan \\
\hline Agriculture, forestry and fishing & 3.78 & 0.11 \\
\hline Mining and quarrying & 0.61 & 0.08 \\
\hline Manufacturing & 55.69 & 68.53 \\
\hline - Food products, beverages and tobacco & 6.94 & 0.56 \\
\hline - Textiles, wearing apparel, leather and related products & 2.77 & 0.47 \\
\hline - Wood and paper products; printing & 1.65 & 0.64 \\
\hline - Chemicals and non-metallic mineral products & 14.96 & 11.99 \\
\hline - Basic metals and fabricated metal products & 6.38 & 7.20 \\
\hline - Computers, electronic and electrical equipment & 3.76 & 13.70 \\
\hline - Machinery and equipment, n.e.c & 3.70 & 11.70 \\
\hline -Transport equipment & 14.14 & 20.62 \\
\hline - Other manufacturing; repair and installation of machinery and equipment & 1.39 & 1.65 \\
\hline Electricity, gas, water supply, sewerage, waste and remediation services & 0.34 & 0.00 \\
\hline Construction & 0.24 & 0.03 \\
\hline Total business sector services & 37.29 & 31.01 \\
\hline Public admin, education and health; social and personal services & 2.04 & 0.25 \\
\hline
\end{tabular}

SOURCE: Own elaboration using the OECD database.

shows a trade profile more specialized in agriculture and services. Besides, the magnitudes of the Economic Complexity Index for Japan and Spain were 2.44 and 0.87 in 2015 , respectively, and both countries are ranked as $1^{\text {st }}$ and $32^{\text {nd }}$ according to the complexity of their set of exported products. ${ }^{2}$ As expected, trade profiles are not homogeneous between countries even with similar levels of growth and development, and the result obtained from Table 1 denotes that Japan is more likely to participate in GVCs than Spain, given that its set of exported products is more sophisticated.

In contrast, other methodologies allow us to estimate country participation in GVCs directly. To this end, we distinguish two approaches for measuring participation in GVCs. The first approach applies a decomposition of trade through input-output tables in order to estimate the amount of trade in intermediate products (e.g. Trefler \& Zhu, 2010; Johnson \& Noguera, 2012a, 2012b). Other methodological approaches depart from Rauch and Trindade (2002) and Chaney (2014) by exploiting the network structure of trade. Using network analysis techniques, these studies analyse

${ }^{2}$ Retrieved from The Atlas of Economic Complexity (http://atlas.cid.harvard.edu/). The higher the value of the Economic Complexity Index is, the greater the product complexity. 
the global production networks with a view to identifying the core and periphery nodes, which has proved useful in identifying trade dynamics across GVCs (e.g., De Benedictis et al., 2014; Gómez et al., 2017; De Lombaerde et al., 2018).

As GVCs are continuously evolving, traditional measures of vertical specialization (Hummels et al., 2001; Koopman et al., 2012) may need to be complemented with new measures of GVCs participation that are closer to the business cycle (Wang et al., 2017). Two new measures of GVCs have been developed rooted in the backward and forward industrial linkages of Fujita et al. (1999): the backward and forward participation in GVCs, previously explained in the introduction. As a reminder, backward linkage-based participation is associated with importing foreign value added through intermediate inputs in order to produce goods that are exported to other countries. In contrast, forward linkage-based participation refers to domestic value added used by foreign countries in the products they export. ${ }^{3}$ Figures 1 and 2 reflect the degree of backward and forward participation in GVCs for the OECD and a sample of Non-OECD countries during the period 2005-2015, while Figure 3 plots both measures in 2015. The full list of OECD countries used in this study can be found in Table A1 in the Appendix.

FIGURE 1

\section{BACKWARD PARTICIPATION IN GVCS FOR THE OECD AND A SAMPLE OF NON-OECD COUNTRIES, 2005-2015}

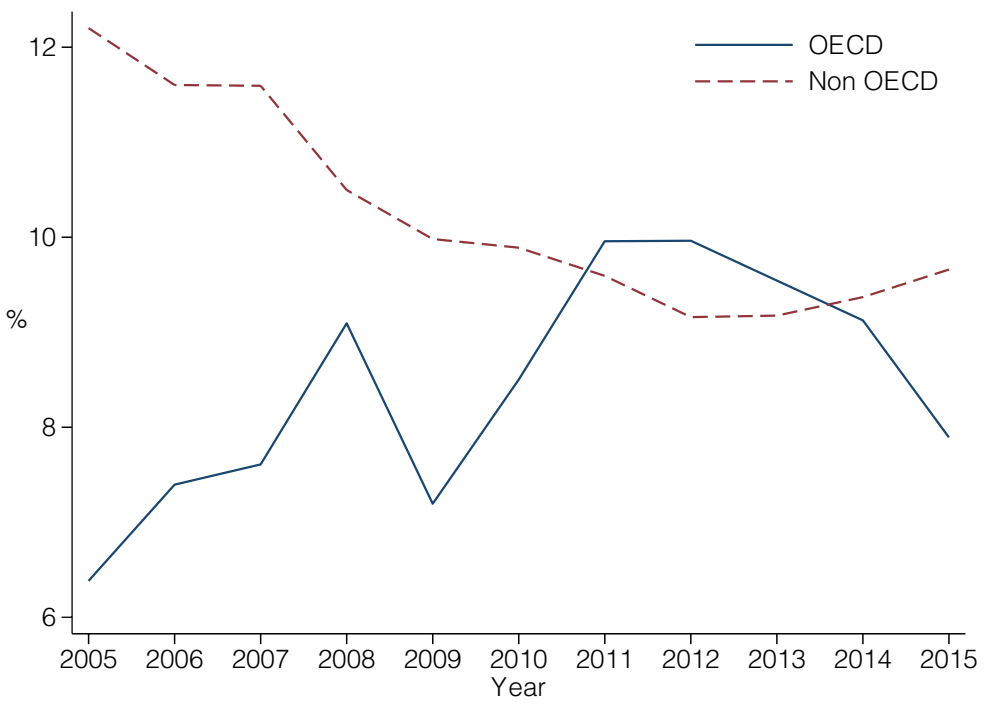

SOURCE: Own elaboration using the OECD database.

3 Backward and forward participation of a country in GVCs are also identified with upstream and downstream, respectively (De Backer \& Miroudot, 2013). 


\section{FIGURE 2}

FORWARD PARTICIPATION IN GVCS FOR THE OECD AND A SAMPLE OF NON-OECD COUNTRIES, 2005-2015

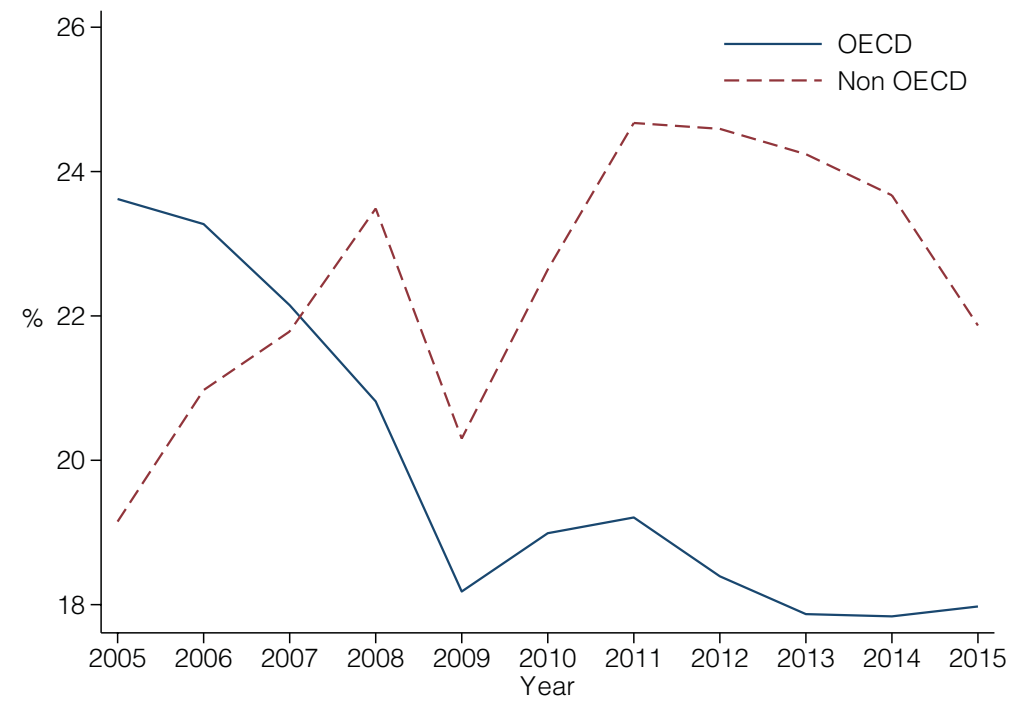

SOURCE: Own elaboration using the OECD database.

FIGURE 3

\section{BACKWARD AND FORWARD PARTICIPATION IN GVCs IN 2015}

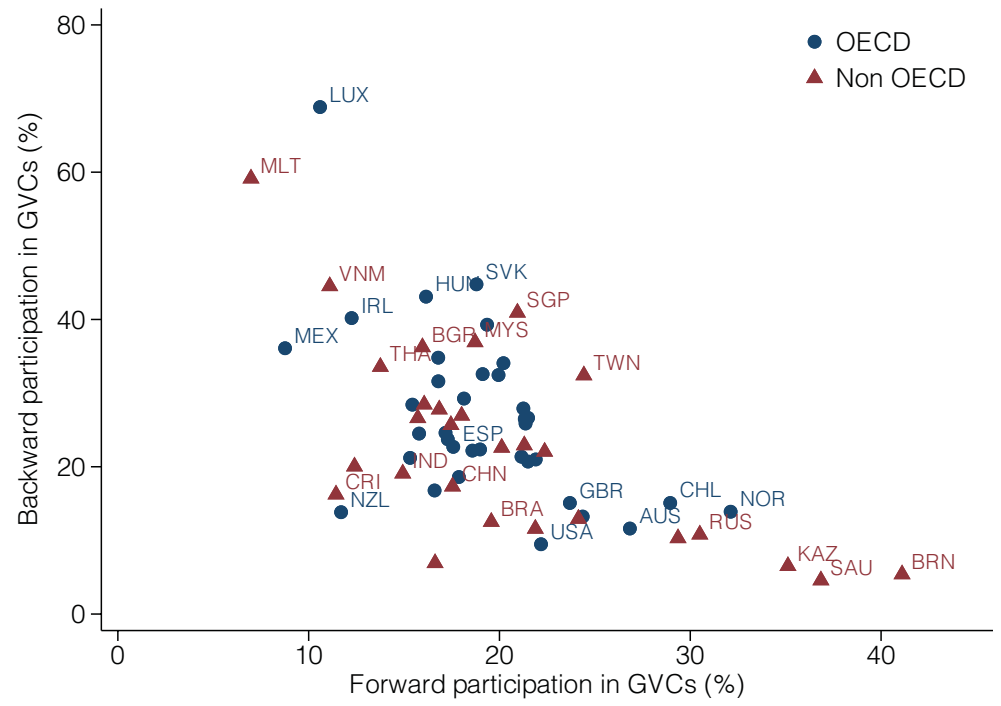

SOURCE: Own elaboration using the OECD database. Countries are shown using ISO-3 country codes. 
As we observe in Figures 1-3, it is necessary to distinguish between backward and forward participation in GVCs, as their behaviour differs for OECD and non-OECD countries. In overall terms, non-OECD countries seem to be more engaged in GVCs participation. Non-OECD countries seem to register higher levels of participation in terms of forward participation, related to domestic products, as shown in Figure 2. However, the gap is considerably lower when studying the backward participation of final products in Figure 1. In fact, the participation of OECD countries in GVCs was higher than in non-OECD countries during the period 2011-2013. In Figure 3, we plot backward and forward participation in GVCs for OECD and non-OECD countries in 2015. As shown in this figure, the participation in GVCs reveals substantial differences across countries. Despite a few exceptions that are mainly oriented to backward (e.g., Malta and Luxembourg) and forward participation in GVCs (e.g., Kazakhstan and Brunei, SAU), the vast majority of countries present balanced participation in GVCs according to backward and forward criteria, but cross-country differences still appear to persist.

To sum up, non-OECD countries seem to be more engaged in forward GVCs participation, although they are also important players in backward participation, as some of these act as production hubs where intermediate inputs are assembled into the final good that is exported (e.g. China and India).

In terms of information and contractual frictions, these are expected to differ between sectors and countries. Countries with better contract enforcement tend to specialize in industries that are contract intensive (Nunn, 2007). For this reason, the effect of institutions may differ according to their degree of participation in GVCs. Sectors with higher degrees of contract enforcement not only avoid production delays in GVCs, but they also tend to be associated with greater backward participation in GVCs (World Bank, 2020). These countries may exhibit an advanced manufacturing industry that can incorporate more value added to intermediate products. In contrast, countries with higher political instability are specialized, usually in products more intensive in natural resources and stand upstream in GVCs (World Bank, 2020). As these countries are not necessarily associated with maintaining a strong advantage in the manufacturing sector, but in the primary sector, they are unable to concentrate on those stages of the production process where the highest shares of value added are embedded into the product.

Table 2 shows the relationship between backward participation and institutional quality disaggregated by sector taxonomy group. The lowest backward participation in GVCs is found in commodities, which also present a low political stability index and the highest average number of days to import. 
TABLE 2

DETERMINANTS OF BACKWARD PARTICIPATION IN GVCS BY TAXONOMY GROUP

\begin{tabular}{|l|c|c|c|}
\hline \multicolumn{1}{|c|}{ Taxonomy group } & $\begin{array}{c}\text { Average backward } \\
\text { GVC participation } \\
\text { share (\%) }\end{array}$ & $\begin{array}{c}\text { Average political } \\
\text { stability index }\end{array}$ & $\begin{array}{c}\text { Average days to } \\
\text { import }\end{array}$ \\
\hline Commodities & 13.9 & -0.6 & 35.4 \\
\hline Limited manufacturing & 24.1 & -0.3 & 19.9 \\
\hline $\begin{array}{l}\text { Advanced manufacturing } \\
\text { and services }\end{array}$ & 39.8 & 0.1 & 13.0 \\
\hline Innovative activities & 37.3 & 0.8 & 8.9 \\
\hline
\end{tabular}

SOURCE: World Bank (2020, p. 57). All the indicators are computed as an average taking as reference the countries belonging to each taxonomy group.

\subsection{How to measure institutions}

The methodological approaches to measure GVCs seem to be well-defined. An identical situation occurs when trying to measure institutions. However, as highlighted in the introduction, the lack of a universally accepted definition of institutions' quality makes the application of this concept to the data more complex and complicated (Rodríguez-Pose, 2013; Nunn \& Trefler, 2014) than in the case of GVCs.

Despite these definitional limitations, some efforts have been made to measure the performance of institutions. The most usual approach has been to consider the quality of institutions by assuming the existence of different types of institutions, as shown by Acemoglu and Robinson (2012). One of the most important statistical endeavours to measure the quality of institutions was conducted by the World Bank to estimate the Worldwide Governance Indicators (WGI) (Kaufmann et al., 2010, 2015). These indicators are elaborated from surveys which evaluate citizen perceptions of governance. The data are available at country level since 2000 and capture six dimensions of governance - Voice and Accountability, Political Stability and Absence of Violence, Government Effectiveness, Regulatory Quality, Rule of Law and Control of Corruption. The latter represents the sourced data most widely employed to measure the impact of institutional quality on trade (Francois \& Manchin, 2013; Álvarez et al., 2018; Martínez-Zarzoso \& Márquez-Ramos, 2019, among others). We show each of the WGI indicators for the OECD and a sample of non-OECD countries for 2015 in Figure 4. A value of zero indicates that institutional quality is on average. Positive values indicate that institutional quality is above average, while negative values indicate that it is below average. 
FIGURE 4

WORLD GOVERNANCE INDICATORS FOR THE OECD AND A SAMPLE OF NON-OECD COUNTRIES, 2015

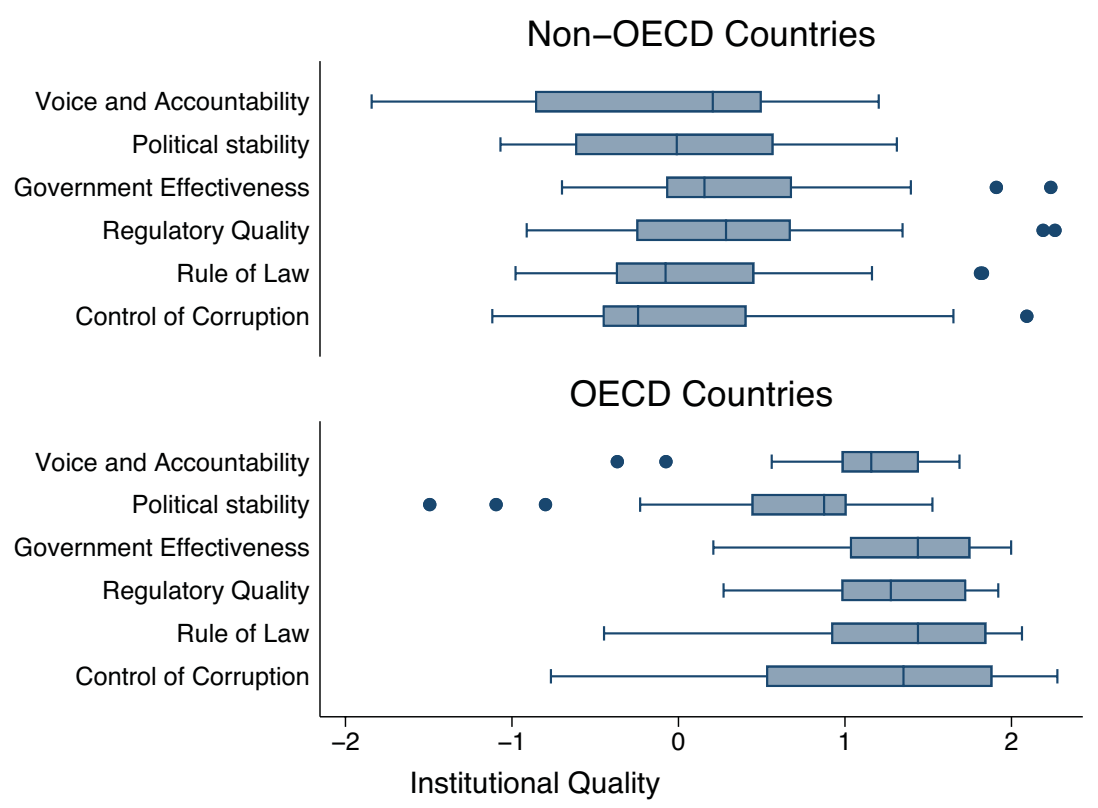

SOURCE: Own elaboration from World Bank using the six estimated indices of WGI. Our sample of non-OECD countries includes only countries for which data on participation in GVCs is available.

As we show in Figure 4, the quality of institutions differs between OECD and nonOECD countries: the average quality of OECD institutions for each one of the six indicators is substantially larger than for our sample of non-OECD institutions. We resort to the most extended framework for the purpose of explaining the differences in quality between institutions. According to Acemoglu and Robinson $(2012,2019)$, there are two types of institutions. While extractive institutions only seek to benefit elites and do not trigger trade competitiveness, inclusive institutions are beneficial for economic performance (i.e., increasing property rights, diffusion of technology and accumulation of human capital) and may result in greater trade competitiveness. In relation to the WGI indicators, extractive institutions tend to be associated with those countries registering low levels of institutional quality.

\subsection{Literature review}

The literature on the effect of institutions on trade has mainly been developed at the country level and bilateral trade. In this context, institutions are considered part of the trade costs, together with geographical and economic variables, and different impacts for exporter and importer country can be identified. 
The initial contributions on the effect of institutions on trade only consider a large sample of countries for specific years or a small subset of countries over time. Anderson and Marcouiller (2002) use a sample of 58 countries trading in 1996 and find that corruption and imperfect contract enforcement are detrimental for trade flows while, at the same time, they may explain the concentration of trade flows between high-income countries. Babetskaia-Koukhartchouk and Maurel (2004) consider the specific case of Russia's accession to WTO during the period 1996-2004 and conclude that the quality of institutions matters to explain trade between CEEC and EU countries. Finally, De Groot et al. (2005) perform a cross-sectional analysis in 1998 for a sample of 114 countries and obtain a positive association between the quality of institutions and trade, stronger in the case of differentiated goods.

While these studies constitute a remarkable approach to the topic, they neglect that improvements in institutional quality may result in greater trade flows over time, as well as the existence of cross-country differences. The contributions raised by Levchenko (2007) and Nunn (2007) consider a global context, including a broader set of countries and also sectoral differences. Levchenko (2007) finds that institutional quality is important to explain US sectoral imports. In contrast, Nunn (2007) extends the discussion to 146 countries and more than 200 industries to find similar results.

After these contributions, the number of empirical studies has increased substantially, shedding light on the effect of institutions on trade. Studies have mainly considered aggregate trade in goods, as the data availability is greater than for services. Méon and Sekkat (2007) use a set of countries for the period 19202000. Their findings suggest that trade of manufactured goods is more sensitive to low levels of institutional quality. Francois and Manchin (2013) analyse the impact of institutional quality and infrastructure on trade for a panel of developed and developing countries. They conclude that low levels of institutional quality in developing countries are detrimental for imports from developed countries. Other contributions consider specific geographical areas, as Martínez-Zarzoso and Márquez-Ramos (2019) do for selected Middle East and North African countries, where institutional quality improvements rise trade flows between 1996 and 2013. Other authors find a positive association between the quality of institutions and trade for agricultural products (Fiankor et al., 2019; Lin et al., 2020), which highlights the importance of sectoral specialization.

The number of contributions concerning trade in services is more modest than trade in goods. Beverelli et al. (2017) focus exclusively on trade in services between 143 countries in 2000 to obtain that lower trade restrictions result in greater volumes of services' trade. Finally, Álvarez et al. (2018) consider trade in goods and services simultaneously to find that institutional quality registers greater effects for trade in agricultural products.

While the literature on the effect of institutions on trade has suggested a positive association between the quality of institutions and trade, a considerable number of issues need to be further explored. Among the most important ones, we find that the discussion has mainly focused on trade in final products, leaving intermediate 
products' transformation through GVCs absent from the debate. These studies only refer to specific areas, such as China (Ge et al., 2020), Africa (Efogo, 2020) or Indonesia (Herlina \& Kudo, 2020). To this aim, it is necessary to study whether this effect is also positive in trade across GVCs.

\section{Empirical analysis}

\subsection{Empirical model and estimation strategy}

To accomplish our objective, the empirical model draws on previous studies (Levchenko, 2007; Nunn, 2007; Tinta, 2017; Ge et al., 2020). In this framework, labour and capital endowments, together with other economic and structural factors, are considered as the drivers of participation in GVCs. Equation [1] can be defined as follows:

$$
\begin{aligned}
& \ln \text { GVCParticipation }_{i t} \\
& \quad=\beta_{0}+\beta_{1} \text { IQ }_{i t}+\beta_{2} \ln \text { GDPpc }_{i t}+\beta_{3} \ln \text { Openness }_{i t}+\beta_{4} \ln \text { Capital }_{i t} \\
& \quad+\beta_{5} \ln \text { Unemployment }+\mu_{i}+\delta_{t}+u_{i t}
\end{aligned}
$$

Where subscripts $i$ and $t$ denote country and time respectively, and $l n$ refers to the natural logarithm. The list of variables is as follows. GVCparticipation ${ }_{i t}$ is the participation indicator in GVCs, $I Q_{i t}$ is the institutional quality variable, $G D P p c_{i t}$ is the gross domestic product per capita, Openness $_{i t}$ is trade openness, defined as the share of exports plus imports over GDP, Capital $_{i t}$ is gross capital formation, and Unemployment $t_{i t}$ is the unemployment rate. We also control for country $\left(\mu_{i}\right)$ and year $\left(\delta_{t}\right)$ fixed effects in order to capture unobservable specificities of countries and business cycles. Finally, $u_{i t}$ is the error term.

The reason for including these variables is explained as follows. Institutional quality has been considered as an explanatory variable in multiple studies (Nunn, 2007; Francois \& Manchin, 2013; Álvarez et al., 2018, among others) due to its capacity to decrease trade costs, and it is our variable of interest. GDP per capita captures economic development since the effects of institutional quality on trade is expected to differ by levels of economic development (Francois \& Manchin, 2013; Urata \& Baek, 2017). Openness is included to estimate the impacts exerted by trade liberalization on countries' participation in GVCs (Urata \& Baek, 2017). Capital aims to control the traditional sources of comparative advantage, since greater capital accumulation leads to higher productivity and growth (Levchenko, 2007; Ge et al., 2020). In contrast, unemployment is related to labor market disparities due to unskilled labor (World Bank, 2020), as more GVC integration is associated with higher unemployment levels. 
Equation [1] is estimated following a panel data random effects model. By using random effects, instead of performing a pooled OLS regression, we can capture any existing unobservable cross-country heterogeneity. The random effects model assumes that the individual unobservable heterogeneity is uncorrelated with the independent variables. We test the use of the random effects model against the fixed effects model using the Hausman (1978) specification test.

An important empirical concern is whether these results may be driven by endogeneity, since those countries with greater participation in GVCs may be coincident with those having higher levels of institutional quality and trade openness, or the existence of unobservable determinants. To avoid endogeneity problems, we resort to taking 1-year lagged values of the variables potentially subject to endogeneity, following prior studies (Urata \& Baek, 2017, Álvarez et al., 2018).

\subsection{Data}

Data on participation in global value chains is sourced from the 2018 edition of the OECD Trade in Value Added (TiVA) database. This database provides GVCs integration indicators for 64 countries between 2005 and 2015. GVCs participation indicators are constructed using data on 36 sectors from the OECD Inter-Country Input-Output (ICIO) tables. The full list of countries is shown in Table A1 of the Appendix.

The Worldwide Governance Indicators (Kaufmann et al., 2010, 2015) provide six governance indicators for over 200 countries over the period 1996-2018, capturing different dimensions of institutional quality at a national level. These indicators are measured in standardized differences from the mean, with a zero-value indicating that a country coincides on average with the others. Positive values indicate that the country's institutional quality is above average, while negative values indicate that it is below average. As mentioned before, each of the six indicators captures a different dimension of institutional quality: Voice and Accountability (VA), Political Stability and Absence of Violence (PV), Government Effectiveness (GE), Regulatory Quality (RQ), Rule of Law (RL), and Control of Corruption (CC).

The source of the remaining variables is as follows. Data on gross domestic product per capita at purchasing power parity at constant 2007 U.S. dollars, gross capital formation as a percentage of GDP, and unemployment as a percentage of the total labour force are taken from The World Bank's World Development Indicators. The variables and their main descriptive statistics are shown in Table A2 of the Appendix. 


\section{Results}

Table 3 displays the results of estimating equation [1] to explain backward participation in GVCs as the dependent variable, whereas Table 4 shows the results for forward participation. Both tables contain the results for each one of the six indicators of institutional quality.

TABLE 3

PANEL RANDOM EFFECTS ESTIMATION RESULTS: BACKWARD PARTICIPATION AND INSTITUTIONAL QUALITY, 2005-2015

\begin{tabular}{|c|c|c|c|c|c|c|}
\hline & (1) & (2) & (3) & (4) & $(5)$ & (6) \\
\hline Voice and Accountability & $\begin{array}{c}0.127 * * * \\
(0.046)\end{array}$ & & & & & \\
\hline Political stability & & $\begin{array}{c}0.012 \\
(0.037)\end{array}$ & & & & \\
\hline Government Effectiveness & & & $\begin{array}{c}-0.011 \\
(0.035)\end{array}$ & & & \\
\hline Regulatory Quality & & & & $\begin{array}{c}0.005 \\
(0.033)\end{array}$ & & \\
\hline Rule of Law & & & & & $\begin{array}{c}0.026 \\
(0.069) \\
\end{array}$ & \\
\hline Control of Corruption & & & & & & $\begin{array}{c}0.043 \\
(0.034) \\
\end{array}$ \\
\hline Log GDP per capita & $\begin{array}{c}-0.185^{* * *} \\
(0.047) \\
\end{array}$ & $\begin{array}{c}-0.128 * * * \\
(0.046) \\
\end{array}$ & $\begin{array}{c}-0.112 * * * \\
(0.043) \\
\end{array}$ & \begin{tabular}{|c|}
$0.123 * * *$ \\
$(0.041)$ \\
\end{tabular} & $\begin{array}{c}-0.136 * * * \\
(0.047)\end{array}$ & $\begin{array}{c}-0.155^{* * * *} \\
(0.042)\end{array}$ \\
\hline Log Openness & $\begin{array}{c}0.571 * * * \\
(0.075)\end{array}$ & $\begin{array}{c}0.548 * * * \\
(0.081)\end{array}$ & $\begin{array}{c}0.555 * * * \\
(0.081)\end{array}$ & $\begin{array}{c}0.552 * * * \\
(0.081)\end{array}$ & $\begin{array}{c}0.552 * * * \\
(0.083)\end{array}$ & $\begin{array}{c}0.550 * * * \\
(0.083)\end{array}$ \\
\hline Log Capital & $\begin{array}{c}0.159 * * * \\
(0.058) \\
\end{array}$ & $\begin{array}{c}0.179 * * * \\
(0.058) \\
\end{array}$ & $\begin{array}{c}0.181 * * * \\
(0.062) \\
\end{array}$ & \begin{tabular}{|c|}
$0.179 * * *$ \\
$(0.060)$ \\
\end{tabular} & $\begin{array}{c}0.177 * * * \\
(0.065) \\
\end{array}$ & $\begin{array}{c}0.171 * * * \\
(0.063) \\
\end{array}$ \\
\hline Log Unemployment & $\begin{array}{c}0.091 * * \\
(0.037)\end{array}$ & $\begin{array}{c}0.107 * * * \\
(0.038)\end{array}$ & $\begin{array}{c}0.108 * * * \\
(0.039)\end{array}$ & $\begin{array}{c}0.107 * * * \\
(0.038)\end{array}$ & $\begin{array}{c}0.105 * * \\
(0.041)\end{array}$ & $\begin{array}{c}0.101 * * \\
(0.039)\end{array}$ \\
\hline Constant & $\begin{array}{c}1.730 * * * \\
(0.623) \\
\end{array}$ & $\begin{array}{c}1.239 * * \\
(0.586) \\
\end{array}$ & $\begin{array}{c}1.053 \\
(0.740) \\
\end{array}$ & $\begin{array}{l}1.175^{*} \\
(0.623) \\
\end{array}$ & $\begin{array}{c}1.302 \\
(0.871) \\
\end{array}$ & $\begin{array}{l}1.512 * * \\
(0.733) \\
\end{array}$ \\
\hline Observations & 630 & 630 & 630 & 630 & 630 & 630 \\
\hline R-square & 0.631 & 0.494 & 0.483 & 0.492 & 0.508 & 0.513 \\
\hline Hausman & 26.00 & 12.65 & 26.23 & 17.91 & 16.41 & 40.06 \\
\hline p-value & 0.026 & 0.554 & 0.024 & 0.211 & 0.289 & 0.000 \\
\hline
\end{tabular}

NOTE: Robust standard errors in parentheses. $* * *, * *$, and $*$ denotes significance at the $0.01,0.05$ and 0.10 level, respectively. All estimations include year fixed effects. Trade openness and institutional variables are lagged one year to prevent endogeneity issues. 
The results obtained show that the relationship between institutional quality and backward participation in GVCs is non-significant for five institutional dimensions. However, it proves positive and statistically significance for Voice and Accountability (column 1), where the magnitude reaches 0.127 . As the institutional quality indicators are measured as standardized differences from the mean, results indicate that countries with voice and accountability one standard deviation over the mean are, on average, $12.7 \%$ more integrated into global value chains than countries with average institutional quality in this dimension. These results confirm that the effect of institutional quality on GVCs participation is sensitive to the dimension of the institutions under consideration. Although governmental effectiveness in the provision of public services and policy development does not seem relevant with reference to a country's participation in backward value chains, the ability of citizens to choose their government representatives and the existence of civil liberties and respect for human rights are important factors supporting the integration into GVCs.

The rest of the variables has the following influence. GDP per capita shows a negative but significant coefficient. This fact may be contradictory, as countries with higher levels of economic development are expected to participate more in GVCs. However, multiple low and middle-income countries act as production hubs, importing intermediate inputs with high value added content which are subsequently assembled to produce and export final goods (e.g. the cases of India and China). ${ }^{4}$ This result could reflect the fact that some countries with low levels of economic development are performing a key role in the intermediate stages of GVCs. Based on our results, we also confirm that greater trade openness is associated with more backward participation in GVCs. It is worth mentioning, that increasing product sophistication of final goods may be related to a higher demand for foreign inputs. The positive and significant estimated coefficient for capital, between 0.159 and 0.181 , can be explained from a corporate perspective, given that firms involved in GVCs tend to be more capital-intensive (Ge et al., 2020). Unemployment coefficients are also positive, indicating that the share of low-skilled workers matters for backward participation in GVCs: those countries with a larger share of low-skilled labour in 2000 become specialized in limited or advanced manufacturing ten years later (World Bank, 2020), and countries with larger shares of low-skilled workers tend to have larger unemployment rates in a significant number of developing countries whose economic structures are oriented to sectors with low value added.

We now proceed to discuss the main results obtained for forward participation in GVCs, which are presented in Table 4.

\footnotetext{
${ }^{4}$ Data confirm this finding. At the aggregate level, the average backward participation share for East Asia and Pacific is $20 \%$, which is ranked in second place after the European Union with $28.9 \%$ (World Bank, 2020, p. 58).
} 
TABLE 4

PANEL RANDOM EFFECTS ESTIMATION RESULTS: FORWARD PARTICIPATION AND INSTITUTIONAL QUALITY, 2005-2015

\begin{tabular}{|c|c|c|c|c|c|c|}
\hline & (1) & (2) & (3) & (4) & (5) & (6) \\
\hline Voice and Accountability & $\begin{array}{l}-0.029 \\
(0.026)\end{array}$ & & & & & \\
\hline Political stability & & $\begin{array}{l}0.043^{*} \\
(0.024)\end{array}$ & & & & \\
\hline Government Effectiveness & & & $\begin{array}{c}0.038 \\
(0.033) \\
\end{array}$ & & & \\
\hline Regulatory Quality & & & & $\begin{array}{c}0.026 \\
(0.042)\end{array}$ & & \\
\hline Rule of Law & & & & & $\begin{array}{c}0.101 * * \\
(0.047) \\
\end{array}$ & \\
\hline Control of Corruption & & & & & & $\begin{array}{c}0.031 \\
(0.033)\end{array}$ \\
\hline Log GDP per capita & $\begin{array}{r}-0.013 \\
(0.043)\end{array}$ & $\begin{array}{l}-0.054 \\
(0.039)\end{array}$ & $\begin{array}{l}-0.055 \\
(0.039)\end{array}$ & $\begin{array}{r}-0.047 \\
(0.041)\end{array}$ & $\begin{array}{c}-0.091 * * \\
(0.042)\end{array}$ & $\begin{array}{l}-0.055 \\
(0.048) \\
\end{array}$ \\
\hline Log Openness & $\begin{array}{c}-0.195 * * * * \\
(0.060)\end{array}$ & $\begin{array}{c}-0.196 * * * \\
(0.062)\end{array}$ & $\begin{array}{c}-0.194 * * * \\
(0.061)\end{array}$ & $\begin{array}{c}-0.194 * * * * \\
(0.061)\end{array}$ & $\begin{array}{c}-0.195 * * * \\
(0.058)\end{array}$ & $\begin{array}{c}-0.193 * * * \\
(0.060)\end{array}$ \\
\hline Log Capital & $\begin{array}{c}0.012 \\
(0.039) \\
\end{array}$ & $\begin{array}{c}0.002 \\
(0.038) \\
\end{array}$ & $\begin{array}{c}0.005 \\
(0.036) \\
\end{array}$ & $\begin{array}{c}0.003 \\
(0.038) \\
\end{array}$ & $\begin{array}{l}-0.005 \\
(0.030) \\
\end{array}$ & $\begin{array}{c}0.001 \\
(0.037) \\
\end{array}$ \\
\hline Log Unemployment & $\begin{array}{l}0.038^{*} \\
(0.023) \\
\end{array}$ & $\begin{array}{c}0.035 \\
(0.022) \\
\end{array}$ & $\begin{array}{c}0.032 \\
(0.022) \\
\end{array}$ & $\begin{array}{c}0.034 \\
(0.023) \\
\end{array}$ & $\begin{array}{c}0.026 \\
(0.020) \\
\end{array}$ & $\begin{array}{c}0.030 \\
(0.022) \\
\end{array}$ \\
\hline Constant & $\begin{array}{c}3.839 * * * \\
(0.511)\end{array}$ & $\begin{array}{c}4.253 * * * \\
(0.501)\end{array}$ & $\begin{array}{c}4.243 * * * \\
(0.440)\end{array}$ & $\begin{array}{c}4.173 * * * \\
(0.431)\end{array}$ & $\begin{array}{c}4.616^{* * *} * \\
(0.546)\end{array}$ & $\begin{array}{c}4.266^{* * * *} \\
(0.584)\end{array}$ \\
\hline Observations & 630 & 630 & 630 & 630 & 630 & 630 \\
\hline R-square & 0.147 & 0.101 & 0.107 & 0.111 & 0.0751 & 0.109 \\
\hline Hausman & 21.95 & 8.581 & 9.828 & 7.304 & 15.75 & 7.597 \\
\hline p-value & 0.080 & 0.857 & 0.775 & 0.922 & 0.329 & 0.909 \\
\hline
\end{tabular}

NOTE: Robust standard errors in parentheses. ***,**, and * denotes significance at the $0.01,0.05$ and 0.10 level, respectively. All estimations include year fixed effects. Trade openness and institutional variables are lagged one year to prevent endogeneity issues.

The relationship between institutional quality and forward participation in GVCs is positive for two dimensions: Political Stability and Rule of Law in columns 2 and 5, respectively. However, it must be noted that the size of coefficients is smaller than in the case of backward participation: 0.043 and 0.101 , respectively. This is in line with our prior comment that countries with abundant natural resources are associated with forward participation in GVCs, and these countries tend to have weaker institutions. ${ }^{5}$

5 This finding depends on the type of natural resources. While it is confirmed for countries abundant in oil and mineral resources, the situation becomes the opposite for countries abundant in land and selling agriculture products (e.g., Australia, Canada, and New Zealand). 
Improving the confidence in the judicial system, judicial independence, contract enforcement, the respect of property rights, and law enforcement against organized crime, together with better political stability, would serve to enhance a greater participation of countries in GVCs. These results also have an important sectoral dependence, as better institutional quality is associated with greater participation in GVCs for the most contractually intensive sectors (World Bank, 2020). The smaller size of the effects obtained for forward participation suggests that this type of participation may be involved in sectors less contractually-intensive. While industries such as poultry, flour milling and petroleum refineries are identified as the least contract-intensive, photography and advanced manufacturing are associated with high contract enforcement. ${ }^{6}$ This disaggregated industry classification can contribute to explaining sectoral performance.

With respect to the remaining variables, some of them display magnitudes which are the reverse to those for backward integration. First, GDP per capita is also negative, but only significant in one scenario (column 5). This confirms the negative relationship between economic development and GVCs participation -although the association between both variables is weak- suggesting that low-income countries contribute more to add value added on inputs (backward) than to provide inputs to others (forward). In contrast to backward integration, trade openness is negative, which is in line with our prior explanation regarding the institutional quality variable: countries exhibiting greater forward participation may be less opened to trade, as they tend to be specialized in less tradeable sectors, such as mining (World Bank, 2020). Countries situated at the first stage of the GVCs might export a high proportion of goods for use as intermediate inputs, but their imports might be small, leading to small values of trade openness. In this case, capital is positive but not statistically significant. This fact may be related to the positive relationship between natural resources and forward participation (World Bank, 2020), and that countries situated at the first stages of value chains are often more labour abundant.

\section{Conclusions}

In this article, we analyse the effect of institutional quality on participation in GVCs. To this end, we distinguish between backward and forward participation in GVCs and consider six dimensions of institutional quality. Using a sample of 63 countries during the period 2005-2015, we find that the effect of institutional quality on participation in GVCs is positive with a greater effect on backward participation, albeit with a weak association. We also find that the results are sensitive to the dimensions of institutional quality under consideration. Voice and accountability, rule of law, and political stability are the most important institutional dimensions associated with participation in GVCs.

\footnotetext{
${ }^{6}$ The most and least contract-intensive industries are retrieved from Nunn (2007).
} 
These results pose important policy implications. In the near future, countries could potentially improve their participation in GVCs, by increasing the quality of their institutions. Institutional quality may interplay with other important determinants, such as technology or geography. In addition, it could prove advantageous for countries to increase their participation in backward GVCs, as the latter are related to more contractually intensive sectors in countries with higher institutional quality (World Bank, 2020), thereby benefiting more from increasing institutional quality and also generating spillovers that may influence sectors with low institutional quality. The greater trade openness induced by participation in GVCs could be beneficial for poorer countries, as they participate more in GVCs. Greater participation in GVCs may result in more growth and prosperity, which may represent a key asset for countries to begin the recovery from the current COVID-19 economic crisis.

This topic presents interesting avenues for consideration in future studies: First, as noted by Timmer et al. (2014), it is necessary to integrate micro and macro statistics to obtain more sophisticated measures of GVCs participation and check whether the impact of institutional quality holds the positive relationship with GVCs participation. Second, this relationship may be explored at the subnational level, as production processes are distributed across regions within the same country, which may bring valuable insights for formulating place-based policies (Mandras \& Conte, 2020). However, this endeavour requires accurate regional trade and institutional quality statistics. Third, this analysis may be extended to trade in services to study the effect of institutions in service GVCs in the context of progressive economic servicification, as demonstrated by some recent studies (Miroudot \& Cadestin, 2017; Thangavelu et al., 2018). Fourth, future studies may need to consider the impacts of institutional quality on trade by bringing other variables into the discussion, such as foreign direct investment or a trade restrictiveness index. Finally, it would be important to distinguish the effects of institutional quality on GVC participation among different income levels, given the prominent levels of GVC participation of certain developing countries, such as China or India.

\section{References}

Acemoglu, D., \& Robinson, J. A. (2012). Why nations fail: The origins of power, prosperity, and poverty. Crown Publishing Group.

Acemoglu, D., \& Robinson, J. A. (2019). The narrow corridor: States, societies, and the fate of liberty. Penguin.

Alfaro, L., Chor, D., Antras, P., \& Conconi, P. (2019). Internalizing global value chains: A firm-level analysis. Journal of Political Economy, 127(2), 508-559.

Álvarez, I. C., Barbero, J., Rodríguez-Pose, A., \& Zofío, J. L. (2018). Does institutional quality matter for trade? Institutional conditions in a sectoral trade framework. World Development, 103, 72-87. 
Anderson, J. E., \& Marcouiller, D. (2002). Insecurity and the pattern of trade: An empirical investigation. Review of Economics and statistics, 84(2), 342-352.

Antràs, P., \& Chor, D. (2013). Organizing the global value chain. Econometrica, 81(6), 2127 2204.

Araujo, L., Mion, G., \& Ornelas, E. (2016). Institutions and export dynamics. Journal of International Economics, 98, 2-20.

Babetskaia-Kukharchuk, O., \& Maurel, M. (2004). Russia's accession to the WTO: the potential for trade increase. Journal of Comparative Economics, 32(4), 680-699.

Baldwin, R. (2016). The Great Convergence. Harvard University Press, Cambridge.

Baldwin, R., \& Tomiura, E. (2020). Thinking ahead about the trade impact of COVID-19. In Baldwin, R. and Weder di Mauro, B. (Eds.), Economics in the Time of COVID-19. CEPR Press.

Bernard, A. B., \& Moxnes, A. (2018). Networks and trade. Annual Review of Economics, 10, 65-85.

Beverelli, C., Fiorini, M., \& Hoekman, B. (2017). Services trade policy and manufacturing productivity: The role of institutions. Journal of International Economics, 104, 166-182.

Chaney, T. (2014). The network structure of international trade. American Economic Review, 104(11), 3600-3634.

De Backer, K., \& Miroudot, S. (2013). Mapping global value chains. OECD Trading Policy Paper, No. 159. Organization for Economic Cooperation and Development.

De Benedictis, L., Nenci, S., Santoni, G., Tajoli, L., \& Vicarelli, C. (2014). Network analysis of world trade using the BACI-CEPII dataset. Global Economy Journal, 14(3-4), $287-$ 343.

De Groot, H. L., Linders, G. J. M., \& Rietveld, P. (2005). Institutions, governance and international trade: opening the black box of OECD and GDP per capita effects in gravity equations. IATSS Research, 29(2), 22-29.

De Lombaerde, P., Iapadre, L., McCranie, A., \& Tajoli, L. (2018). Using network analysis to study globalization, regionalization, and multi-polarity-Introduction to special section. Network Science, 6(4), 494-516.

Dollar, D., \& Kidder, M. (2017). Institutional quality and participation in global value chains. In WTO (Ed) Global Value Chain Development Report: Measuring and Analyzing the Impact of GVCs on Economic Development (pp. 161-173). World Trade Organization.

Efogo, F. O. (2020). Financial Development and African Participation in Global Value Chains. In D. Seck (Ed), Financing Africa's Development (pp. 33-52). Springer.

ESCAP (2015) Asia-Pacific trade and investment report 2015: Supporting Participation in Global Value Chains. ESCAP.

Fiankor, D., Martínez-Zarzoso, I., \& Brümmer, B. (2019). Exports and governance: the role of private voluntary agrifood standards. Agricultural Economics, 50(3), 341-352.

Francois, J., \& Manchin, M. (2013). Institutions, infrastructure, and trade. World Development, 46, 165-175.

Fujita, M., Krugman, P. R., \& Venables, A. (1999). The spatial economy: Cities, regions, and international trade. MIT press.

Ge, Y., Dollar, D., \& Yu, X. (2020). Institutions and participation in global value chains: Evidence from belt and road initiative. China Economic Review, 61, 101447.

Glaeser, E. L., La Porta, R., Lopez-de-Silanes, F., \& Shleifer, A. (2004). Do institutions cause growth? Journal of economic Growth, 9(3), 271-303. 
Gómez, L. B., Mora, C. D., \& Díaz, B. G. (2017). La servitización de las cadenas globales de valor: una aproximación a partir del análisis de redes sociales. Cuadernos Económicos de ICE, 94, 87-114.

Hanson, G. H. (2012). The rise of middle kingdoms: Emerging economies in global trade. Journal of Economic Perspectives, 26(2), 41-64.

Hausman, J. A. (1978). Specification Tests in Econometrics. Econometrica, 46(6), 12511271.

Hausmann, R., \& Hidalgo, C. (2011). The network structure of economic output. Journal of Economic Growth, 16(4), 309-342.

Hausmann, R., Hidalgo, C. A., Bustos, S., Coscia, M., Simoes, A., \& Yildirim, M. A. (2014). The atlas of economic complexity: Mapping paths to prosperity (2 ${ }^{\text {nd }}$ Edition). MIT Press.

Herlina, E. H., \& Kudo, T. (2020). Institutions and Firm's Participation in the Global Production Network (GPN): Firm-Level Analysis in Indonesia. Jurnal Ekonomi dan Studi Pembangunan, 12(1), 26-44.

Hummels, D., Ishii, J., \& Yi, K-M. (2001). The Nature and Growth of Vertical Specialization in World Trade. Journal of International Economics, 54(1), 75-96.

Johnson, R. C. (2014). Five facts about value-added exports and implications for macroeconomics and trade research. Journal of Economic Perspectives, 28(2), 119-42.

Johnson, R. C., \& Noguera, G. (2012a). Accounting for intermediates: Production sharing and trade in value added. Journal of international Economics, 86(2), 224-236.

Johnson, R. C., \& Noguera, G. (2012b). Proximity and production fragmentation. American Economic Review, 102(3), 407-411.

Kauffmann, D., Kraay, A., \& Mastruzzi, M. (2010). The worldwide governance indicators: A summary of methodology, data and analytical issues. World Bank Policy Research, 2-29.

Kaufmann, D., Kraay, A., \& Mastruzzi, M. (2015). The Worldwide Governance Indicators Project. https://info.worldbank.org/governance/wgi/

Koopman, R., Wang, Z., \& Wei, S. J. (2012). Estimating domestic content in exports when processing trade is pervasive. Journal of Development Economics, 99(1), 178-189.

Koopman, R., Wang, Z., \& Wei, S. J. (2014). Tracing value-added and double counting in gross exports. American Economic Review, 104(2), 459-494.

Levchenko, A. A. (2007). Institutional quality and international trade. The Review of Economic Studies, 74(3), 791-819.

Lin, J., Flachsbarth, I., \& von Cramon-Taubadel, S. (2020). The role of institutional quality on the performance in the export of coconut products. Agricultural Economics, 51(2), 237-258.

Mandras, G., \& Conte, A. (2020). Mapping global value chains. In R. Capello, A. Kleibrink \& M. Matusiak (Eds), Quantitative Methods for Place-Based Innovation Policy (pp. 78108). Edward Elgar.

Martínez-Zarzoso, I., \& Márquez-Ramos, L. (2019). Exports and governance: Is the Middle East and North Africa region different? The World Economy, 42(1), 143-174.

Méon, P. G., \& Sekkat, K. (2008). Institutional quality and trade: which institutions? Which trade? Economic Inquiry, 46(2), 227-240.

Miroudot, S., \& Cadestin, C. (2017). Services in Global Value Chains: From Inputs to ValueCreating Activities. OECD Trade Policy Papers, No. 197. Organization for Economic Cooperation and Development. 
Nunn, N. (2007). Relationship-specificity, incomplete contracts, and the pattern of trade. The Quarterly Journal of Economics, 122(2), 569-600.

Nunn, N., \& Trefler, D. (2014). Domestic institutions as a source of comparative advantage. In G. Gopinath, E. Helpman \& K. Rogoff (Eds), Handbook of international economics (Vol. 4, pp. 263-315). Elsevier.

OECD (2019) Guide to OECD's Trade in Value Added (TiVA) Indicators, 2018 edition. https://www.oecd.org/sti/ind/tiva/TiVA2018_Indicators_Guide.pdf

Rauch, J. E., \& Trindade, V. (2002). Ethnic Chinese networks in international trade. Review of Economics and Statistics, 84(1), 116-130.

Rodríguez-Pose, A. (2013). Do institutions matter for regional development? Regional studies , 47(7), 1034-1047.

Thangavelu, S. M., Wang, W., \& Oum, S. (2018). Servicification in global value chains: Comparative analysis of selected Asian countries with OECD. The World Economy, 41(11), 3045-3070.

Timmer, M. P., Erumban, A. A., Los, B., Stehrer, R., \& De Vries, G. J. (2014). Slicing up global value chains. Journal of Economic Perspectives, 28(2), 99-118.

Tinta, A. A. (2017). The determinants of participation in global value chains: The case of ECOWAS. Cogent Economics \& Finance, 5(1), 1389252.

Trefler, D., \& Zhu, S. C. (2010). The structure of factor content predictions. Journal of International Economics, 82(2), 195-207.

Urata, S., \& Baek, Y. (2020). Does Participation in Global Value Chains Increase Productivity? An Analysis of Trade in Value Added Data. Thailand and The World Economy, 38(1), $1-28$.

Wang, Z., Wei, S. J., Yu, X., \& Zhu, K. (2017). Measures of participation in global value chains and global business cycles (Working Paper No. 23222). National Bureau of Economic Research.

World Bank (2020). World Development Report 2020. Trading for development in the age of Global Value Chains. The World Bank. 


\section{Appendix}

TABLE A1

LIST OF COUNTRIES

\begin{tabular}{|c|c|c|c|}
\hline \multicolumn{2}{|c|}{ OECD Countries (36) } & \multicolumn{2}{|c|}{ Non-OECD Countries (28) } \\
\hline AUS & Australia & $\mathrm{ARG}$ & Argentina \\
\hline AUT & Austria & BRA & Brazil \\
\hline BEL & Belgium & $\mathrm{BRN}$ & Brunei Darussalam \\
\hline CAN & Canada & BGR & Bulgaria \\
\hline CHL & Chile & KHM & Cambodia \\
\hline CZE & Czech Republic & $\mathrm{CHN}$ & China \\
\hline DNK & Denmark & $\mathrm{COL}$ & Colombia \\
\hline EST & Estonia & CRI & Costa Rica \\
\hline FIN & Finland & HRV & Croatia \\
\hline FRA & France & CYP & Cyprus \\
\hline DEU & Germany & $\mathrm{HKG}$ & Hong Kong SAR, China \\
\hline GRC & Greece & IND & India \\
\hline HUN & Hungary & IDN & Indonesia \\
\hline ISL & Iceland & KAZ & Kazakhstan \\
\hline IRL & Ireland & MYS & Malaysia \\
\hline ISR & Israel & MLT & Malta \\
\hline ITA & Italy & MAR & Morocco \\
\hline JPN & Japan & PER & Peru \\
\hline KOR & Korea, Rep. & PHL & Philippines \\
\hline LVA & Latvia & ROU & Romania \\
\hline LTU & Lithuania & RUS & Russian Federation \\
\hline LUX & Luxembourg & SAU & Saudi Arabia \\
\hline MEX & Mexico & SGP & Singapore \\
\hline NLD & Netherlands & $\mathrm{ZAF}$ & South Africa \\
\hline NZL & New Zealand & TWN & Taiwan, China \\
\hline NOR & Norway & THA & Thailand \\
\hline POL & Poland & TUN & Tunisia \\
\hline PRT & Portugal & VNM & Vietnam \\
\hline SVK & Slovak Republic & & \\
\hline SVN & Slovenia & & \\
\hline ESP & Spain & & \\
\hline SWE & Sweden & & \\
\hline CHE & Switzerland & & \\
\hline TUR & Turkey & & \\
\hline GBR & United Kingdom & & \\
\hline USA & United States & & \\
\hline
\end{tabular}


TABLE A2

MAIN DESCRIPTIVE STATISTICS

\begin{tabular}{|l|r|r|r|r|}
\hline \multicolumn{1}{|c|}{ Variable } & \multicolumn{1}{c|}{ Mean } & Std. Dev. & \multicolumn{1}{c|}{ Min } & \multicolumn{1}{c|}{ Max } \\
\hline GVC backward participation (\%) & 19.87 & 6.80 & 5.99 & 41.25 \\
\hline GVC forward participation (\%) & 25.49 & 11.98 & 3.03 & 68.84 \\
\hline Voice and Accountability & 0.59 & 0.90 & -1.91 & 1.74 \\
\hline Political stability & 0.36 & 0.82 & -2.06 & 1.60 \\
\hline Government Effectiveness & 0.86 & 0.80 & -1.00 & 2.44 \\
\hline Regulatory Quality & 0.85 & 0.75 & -1.07 & 2.26 \\
\hline Rule of Law & 0.74 & 0.91 & -1.23 & 2.10 \\
\hline Control of Corruption & 0.70 & 1.01 & -1.25 & 2.47 \\
\hline GDP per capita (U.S. dollars) & $33,135.49$ & $20,092.04$ & $2,120.55$ & $115,415.40$ \\
\hline Openness (\%) & 103.62 & 76.14 & 22.11 & 442.62 \\
\hline Capital (\%) & 24.12 & 5.77 & 10.22 & 46.66 \\
\hline Unemployment (\%) & 7.54 & 4.57 & 0.39 & 29.25 \\
\hline
\end{tabular}

